\title{
Towards Chloride-Free Organic Electrolytes for Rechargeable Aluminum Batteries
}

\author{
Zaher Slim ${ }^{\mathrm{a}}$ and Erik J. Menke *a
}

\section{Broader context}

Environmental implications brought about by global climate challenges and the ever-growing demands for renewable energy resources entail a quest for the development of largescale, cost-effective and efficient energy storage systems. Successful design of rechargeable batteries based on multivalent ions $\left(\mathrm{Mg}^{2+}, \mathrm{Ca}^{2+}\right.$, and $\left.\mathrm{Al}^{3+}\right)$ can have far-reaching impacts on applications such as portable electronics, electric vehicles, and grid storage. As the most abundant metal in the Earth's crust, $\mathrm{Al}$ is an ideal candidate. Metallic $\mathrm{Al}$ anodes can, in theory, provide exceptionally high charge capacities. However, the lack of non-corrosive electrolytes has been a bottleneck in the advancement of a practical rechargeable battery. Shedding light on the electrodeposition of $\mathrm{Al}$ from chloride-free and chloride-rich organic electrolytes may pave the way for the development of next-generation $\mathrm{Al}$-ion batteries. To that end, exploiting $\mathrm{Al}$-based organic electrolytes for energy storage necessitates profound insights into the electrochemical and spectroscopic attributes of $\mathrm{Al}$-ion complexes as will be conveyed by this study.

The corrosivity of chloride-based electrolytes is a major shortcoming in the practical realization of rechargeable aluminum batteries. Herein, the effect of $\mathrm{Cl}^{-}$on $\mathrm{Al}$ speciation and electrochemistry in tetrahydrofuran was measured by employing theoretical and experimental approaches for three systems: $\mathrm{Al}(\mathrm{OTF})_{3} / \mathrm{THF}, \mathrm{Al}(\mathrm{OTF})_{3}$ plus $\mathrm{LiCl}$ in THF, and $\mathrm{AlCl}_{3} / \mathrm{THF}$. The high consistency between measured and computed spectroscopic aspects associated with $\mathrm{Al}(\mathrm{OTF})_{3} / \mathrm{THF}$ electrolyte provided both a rationale for understanding $\mathrm{Al}$ complex-ion formation in a $\mathrm{Cl}^{-}$ free environment and an approach for examining the effect of $\mathrm{Cl}^{-}$ on $\mathrm{Al}$ speciation. Room-temperature $\mathrm{Al}$ plating was achieved from dilute solutions $\left([\mathrm{Al}]=0.1 \mathrm{M}\right.$ ) at potentials $\geq 0 \mathrm{~V}$ (vs. $\left.\mathrm{Al} / \mathrm{Al}^{3+}\right) . \mathrm{Cl}^{-}$ is found to enable facile $\mathrm{Al}$ plating and SEM reveals that $\mathrm{Al}$ is electrochemically deposited as nanocrystalline grains.

The pursuit of high energy density for electrification of the transportation system and the demand for intermittent grid storage along with the significant uncertainty in material supplies for lithium-ion batteries ${ }^{1,2}$ are propelling research efforts towards multivalent ion battery technologies, including those based on magnesium ( $\mathrm{Mg}$ ), calcium (Ca) and aluminum (Al) ${ }^{3,4}$ Among post-lithium( $\mathrm{Li}$ ) ion batteries, $\mathrm{Al}$ is of particular interest because of its superior theoretical volumetric capacity and low-cost compared to $\mathrm{Li}$ and other post- Li battery metals

\footnotetext{
a. Chemistry \& Biochemistry, University of California, Merced, Merced, California 95343, United States

+Electronic Supplementary Information (ESI) available: Full experimental section and additional data are provided. See DOI: 10.1039/x0xx00000x
}

on account of its trivalency and high abundance. ${ }^{5,6}$ However, making use of Al's remarkable capacity is challenging due to its relatively small ionic radius and high charge density, which inevitably leads to the formation of Al-ion complexes rather than "free" Al-ions in commonly employed chloroaluminate ionic liquids, diminishing the expected capacities of $\mathrm{Al}$-ion batteries. ${ }^{7}$ In spite of the recent advances in developing cathode materials, 8,9 and electrolytes, 6,10 the $\mathrm{Al}$-ion battery remains in its infancy. ${ }^{11}$ Accordingly, breaking new ground in Al-ion electrolyte chemistries for rechargeable $\mathrm{Al}$ batteries is of utmost significance.

Due to their ability to electrodeposit/strip $\mathrm{Al}$, chloroaluminate ionic liquids based on aluminum trichloride $\left(\mathrm{AlCl}_{3}\right)$ are often investigated as electrolytes for $\mathrm{Al}$-ion batteries. ${ }^{12-28}$ Nevertheless, their integration into a practical Al-ion battery is hindered by severe drawbacks including the instability of cathode materials in these electrolytes leading to rapid capacity fading, ${ }^{20}$ high corrosivity towards $\mathrm{Al}$ anodes ${ }^{29}$ and stainless steel current collectors, ${ }^{13}$ and side reactions that generate $\mathrm{Cl}_{2}$ gas. ${ }^{30,31}$

Moreover, considering that molten salts are often limited to high operating temperatures, ${ }^{6}$ organic solvents present an appealing choice for room temperature Al-ion battery application. The development of an organic electrolyte, however, is a challenging task that requires a fundamental understanding of the solute/solvent ion-dipole and coulombic interactions. ${ }^{32}$ 
(a)

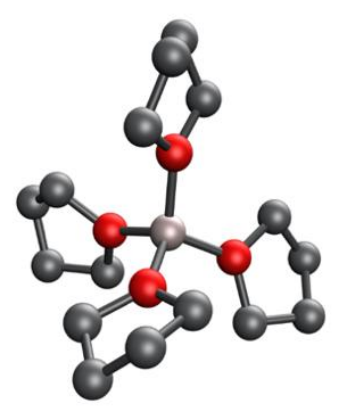

(d)

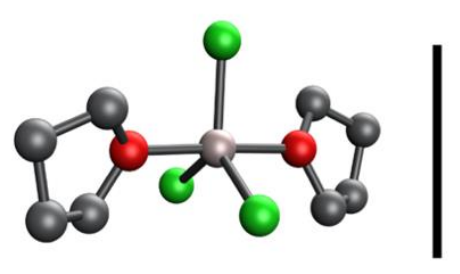

(b)

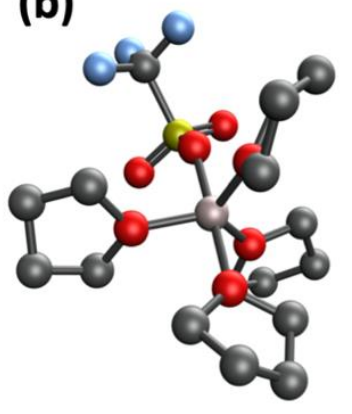

(e)

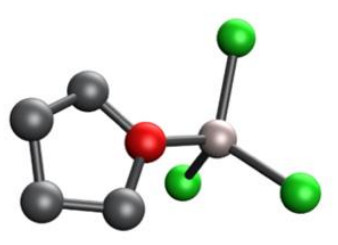

(c)

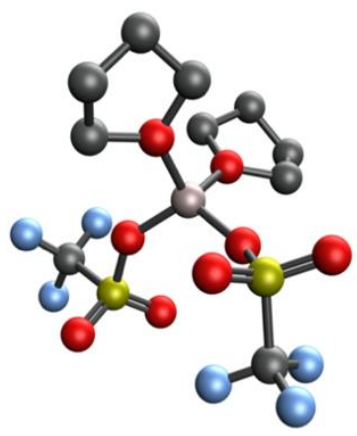

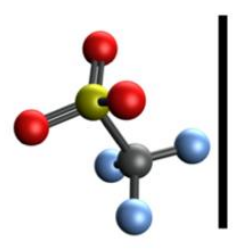

(f)

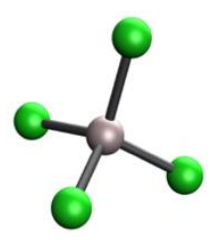

\section{Carbon Oxygen fluorine Aluminum Sulfur Chlorine}

Fig. 1 Optimized structures (hydrogens not shown) of (a) $\mathrm{Al}(\mathrm{THF})_{4}^{3+}$, (b) $\left[\mathrm{Al}(\mathrm{THF})_{4}(\mathrm{OTF})\right][(\mathrm{OTF})]^{+}$, (c) $\left[\mathrm{Al}(\mathrm{THF})_{2}(\mathrm{OTF})_{2}\right]^{+},(\mathrm{d}) \mathrm{AlCl}_{3}(\mathrm{THF})_{2}$,(e) $\mathrm{AlCl}_{3}(\mathrm{THF})$, and (f) $\mathrm{AlCl}_{4}^{-}$.

Tremendous efforts have been dedicated to electrodeposit $\mathrm{Al}$ from a plethora of organic systems including $\mathrm{AlCl}_{3}$ and lithium hydride( $\mathrm{LiH})$ in diethyl ether, ${ }^{33} \mathrm{AlCl}_{3}$ and lithium aluminum hydride $\left(\mathrm{LiAlH}_{4}\right)$ in tetrahydrofuran (THF) and benzene mixture, ${ }^{34} \mathrm{AlCl}_{3}$ and $\mathrm{LiAlH}_{4}$ in $\mathrm{THF}$ and toluene, ${ }^{35} \mathrm{AlCl}_{3}$ and $\mathrm{LiAlH}_{4}$ in $\mathrm{THF}^{36-39}$ aluminum tribromide $\left(\mathrm{AlBr}_{3}\right)$ in aromatic hydrocarbons, ${ }^{40,41} \mathrm{AlBr}_{3}$ in $\mathrm{N}, \mathrm{N}$-dimethylaniline, ${ }^{42} \mathrm{AlBr}_{3}$ and potassium bromide $(\mathrm{KBr})$ in ethylbenzene, ${ }^{43} \mathrm{AlCl}_{3}$ in sulfones, ${ }^{44-49} \mathrm{AlCl}_{3}$ in glycol ethers (glymes), ${ }^{50-53} \mathrm{AlCl}_{3}$ in ethylene carbonate, ${ }^{54}$ and $\mathrm{AlCl}_{3}$ in gamma-butyrolactone (GBL). ${ }^{55}$

Unfortunately, these electrolytes are inherently corrosive and the prospects of practically implementing $\mathrm{Al}$-ion batteries as electrochemical energy storage devices is contingent upon active chloride-free systems. ${ }^{56}$ It is therefore imperative to investigate organic electrolytes based on alternative Al-salts. Inspired by the aforementioned challenges associated with $\mathrm{Al}$ halides, researchers have sought to synthesize novel chloridefree Al-salts, ${ }^{57-59}$ as well as explore the commercially available aluminum trifluoromethanesulfonate $\left(\mathrm{Al}(\mathrm{OTF})_{3}\right){ }^{12,60-63}$ It is worth noting that employing $\mathrm{Al}(\mathrm{OTF})_{3}$ as a potential Al-salt for $\mathrm{Al}$-ion batteries has not been restricted to organic solvents, with its application in aqueous systems $s^{64,65}$ and ionic liquids ${ }^{66}$ having already been demonstrated. Despite these endeavours, the role free chlorides $\left(\mathrm{Cl}^{-}\right)$play in $\mathrm{Al}$-ion organic electrolyte chemistry, and a clear demonstration of $\mathrm{Al}$ electrodeposition using $\mathrm{Al}(\mathrm{OTF})_{3}$, has not yet been established.

In our previous report, ${ }^{63}$ we explored the ionic speciation and the electrochemical activity of $\mathrm{Al}$-complexes in $\mathrm{Al}(\mathrm{OTF})_{3} / \mathrm{THF}$ computationally and experimentally. Density functional theory (DFT) calculations coupled with Fourier transform infrared spectroscopy (FTIR) suggested that Al exists in these solutions as fully solvated Al-complexes, in addition to the presence of inner-sphere and outer-sphere trifluoromethansulfonate anions $\left(\mathrm{OTF}^{-}\right) \cdot{ }^{63}$ Further investigation at higher concentrations $(>0.1 \mathrm{M})$, presented herein, reveals that these solutions are dominated by $\left[\mathrm{Al}(\mathrm{THF})_{2}(\mathrm{OTF})_{2}\right]^{+}$. The structure evolution of these species is depicted in Fig. 1a-c. In light of these findings and to ascertain the effect of $\mathrm{Cl}^{-}$on the electrochemical behaviour of Al-ions, we report here evidence for the electrochemical reduction of $\mathrm{Al}$-ions to Al-metal from THF through a comparative study that reveals the electrochemical behaviour and ionic speciation of Al-complexes in three electrolyte systems: $\mathrm{Al}(\mathrm{OTF})_{3} / \mathrm{THF}, \mathrm{Al}(\mathrm{OTF})_{3}+\mathrm{LiCl} / \mathrm{THF}$, and $\mathrm{AlCl}_{3}$ /THF.

In this work $\mathrm{LiCl}$ was chosen as an additive due to its ability to provide free $\mathrm{Cl}^{-}$in THF, a result of the ionic character of the $\mathrm{Li}-\mathrm{Cl}$ bond in $\mathrm{LiCl}$ compared to the more covalent nature of the $\mathrm{Al}-\mathrm{Cl}$ bonds in $\mathrm{AlCl}_{3}$. To examine the effect of $\mathrm{Cl}^{-}$on $\mathrm{Al}$ speciation, a comprehensive investigation of computed versus measured vibrational frequencies was undertaken, with a summary of the DFT results is provided in the supporting material (Table S1). Our findings on the $\mathrm{AlCl}_{3} / \mathrm{THF}$ solutions complement those of Derouault et al., ${ }^{67}$ where the major species in these solutions were found to be charge neutral $\mathrm{AlCl}_{3}$ (THF) $)_{2}$ and $\mathrm{AlCl}_{3}$ (THF) (shown in Fig. $1 \mathrm{~d}$ and e). The spectral features of the $\mathrm{Al}(\mathrm{OTF})_{3} / \mathrm{THF}$ and $\mathrm{AlCl}_{3} / \mathrm{THF}$ solutions at various concentrations are then used to elucidate the reactions involving $\mathrm{Al}(\mathrm{OTF})_{3}$ and $\mathrm{LiCl}$ in THF. Our results 
(a)

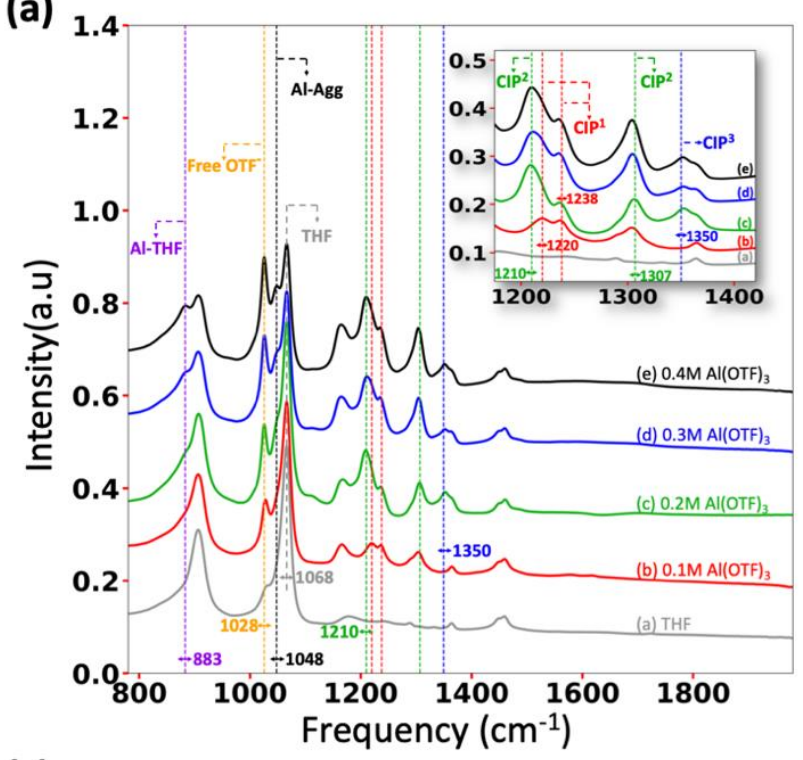

(c)

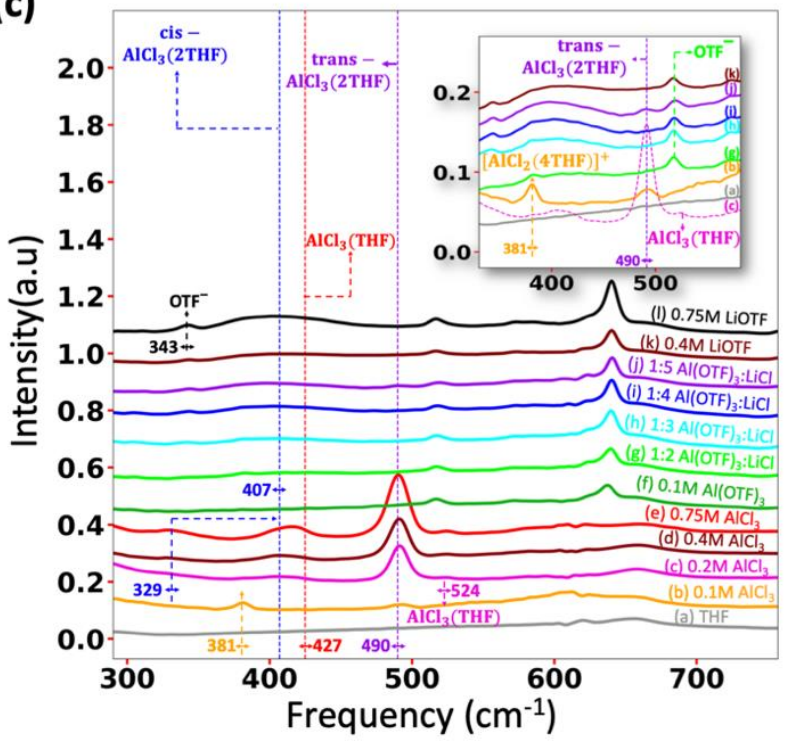

(b)

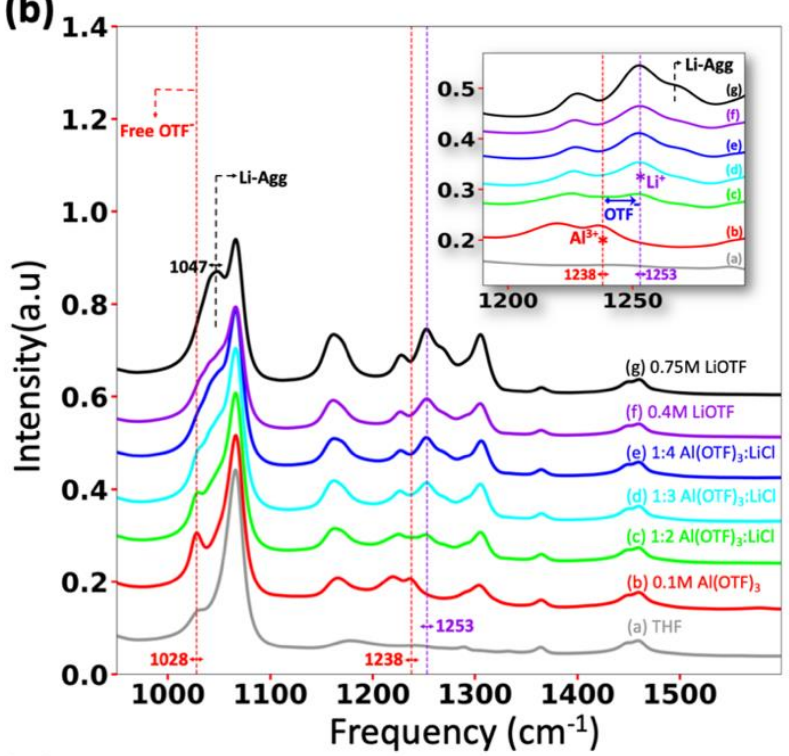

(d)

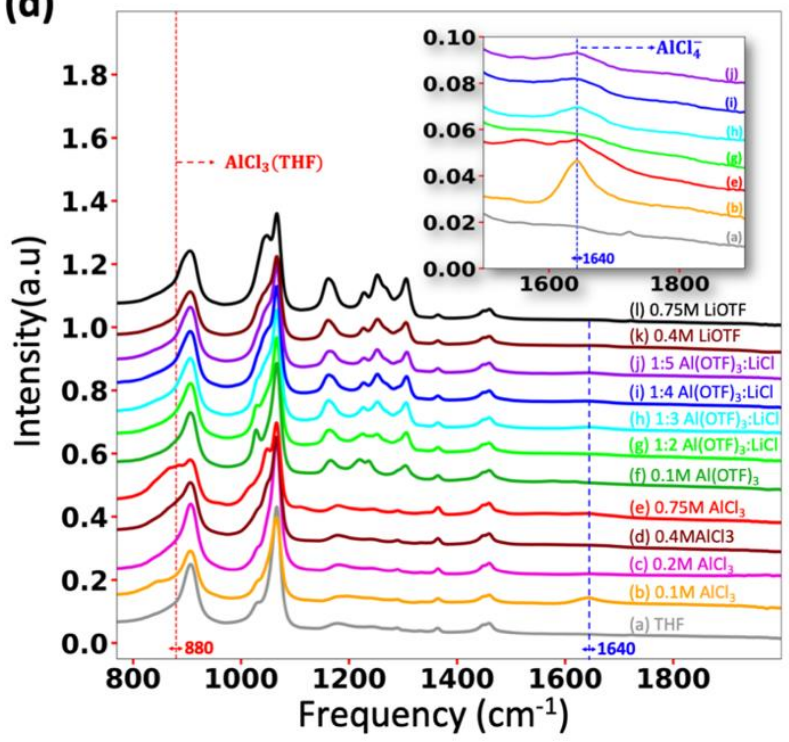

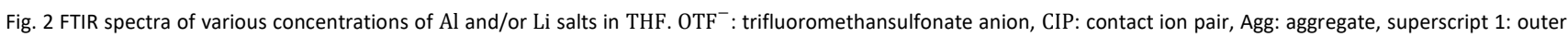
sphere $\mathrm{OTF}^{-}$, superscript 2: inner sphere $\mathrm{OTF}^{-}$, superscript 3: two inner sphere $\mathrm{OTF}^{-}$

suggest that this electrolyte is dominated by $\mathrm{AlCl}_{4}^{-}$(Fig. 1f) at $\mathrm{Al}(\mathrm{OTF})_{3}: \mathrm{LiCl}$ mole ratios equal to or above $1: 3$, in addition to the ionic association between $\mathrm{Li}^{+}$and $\mathrm{OTF}^{-}$in this electrolyte. The striking dissimilarities in the spectroscopic and electrochemical attributes for the $\mathrm{Cl}^{-}$rich environments i.e. $\mathrm{AlCl}_{3} / \mathrm{THF}$ and $\mathrm{Al}(\mathrm{OTF})_{3}+\mathrm{LiCl} / \mathrm{THF}$, provide insight into the role of particular $\mathrm{Cl}^{-}$containing Al-complexes in $\mathrm{Al}$ electrodeposition/stripping behaviour in THF.

A series of electrolyte solutions were prepared by dissolving appropriate amounts of $\mathrm{Al}$-salt $\left(\mathrm{Al}(\mathrm{OTF})_{3}, \mathrm{AlCl}_{3}\right)$ and/or Li-salt (LiOTF, LiCl) in THF. (See Materials and Methods section in ESI) FTIR spectra were collected and are shown in Fig 2.

Initially, it was crucial to examine the spectral regions corresponding to the complex-ion formation in the $\mathrm{Al}(\mathrm{OTF})_{3} / \mathrm{THF}$ electrolyte at various concentrations (Fig. 2a). Previously, ${ }^{63}$ we demonstrated that the peak at $1028 \mathrm{~cm}^{-1}$ is associated with symmetric stretch $\left(v_{\mathrm{s}} \mathrm{SO}_{3}\right)$ of free $\mathrm{OTF}^{-}$and that the $1200-1400 \mathrm{~cm}^{-1}$ region of the spectra displays bands assigned to the antisymmetric stretch of the $\mathrm{OTF}^{-}$anions $\left(v_{\mathrm{as}} \mathrm{SO}_{3}\right)$ for two types of contact ion pairs, outer sphere and inner sphere $\mathrm{OTF}^{-}$, referred to here as $\mathrm{CIP}^{1}$ and $\mathrm{CIP}^{2}$, respectively. Re-examining this region, we find that the broad peak centred at $1210 \mathrm{~cm}^{-1}$ is likely a combination of two spectral components, a peak at $1220 \mathrm{~cm}^{-1}, \mathrm{CIP}^{1}$, assigned to $v_{\text {as }} \mathrm{SO}_{3}$, another, $\mathrm{CIP}^{2}$, at $1210 \mathrm{~cm}^{-1}$ assigned to $v \mathrm{C}-\mathrm{S}$ coupled with $v_{\mathrm{s}} \mathrm{SO} 3$ of $\mathrm{OTF}^{-}$(Table S1). Upon access of an additional $\mathrm{OTF}^{-}$to the inner solvation sphere of the Al-cation, a new peak appears both computationally and experimentally at $\sim 1350 \mathrm{~cm}^{-1}$. We attribute this peak to a third type of contact ion pairs, $\mathrm{CIP}^{3}$, represented by the following species; $\left[\mathrm{Al}(\mathrm{THF})_{2}(\mathrm{OTF})_{2}\right]^{1+}$ and $\left[\mathrm{Al}(\mathrm{THF})_{3}(\mathrm{OTF})_{2}\right]^{1+}$. Although the predicted reaction energies for both complexes are similar 
(Table S2), entropic factors are not accounted for in these calculations. As a result, we attribute the peak at $\sim 1350 \mathrm{~cm}^{-1}$ to the tetrahedral complex $\left[\mathrm{Al}(\mathrm{THF})_{2}(\mathrm{OTF})_{2}\right]^{1+}$.

Moreover, comparing the $\mathrm{Al}(\mathrm{OTF})_{3} / \mathrm{THF}$ spectra to that of pure solvent (THF), we find that the peak at $1068 \mathrm{~cm}^{-1}$ becomes broader as the concentration increases, suggesting that this band is not only associated with THF but also $\mathrm{Al}-\mathrm{CIP}$ and/or Al-aggregates. ${ }^{63,68}$

The peak emerging at $883 \mathrm{~cm}^{-1}$, as supported by our DFT calculations, can be assigned to $v(\mathrm{Al}-\mathrm{O})$ coupled with $\tau \mathrm{CH}_{2}$ of $\mathrm{Al}-\mathrm{THF}$ bond. (See table S1. in ESI) Finally, the peak observed at $1048 \mathrm{~cm}^{-1}$ is more prominent at concentrations $>0.3 \mathrm{M}$ which suggest that this peak may be associated with ionic aggregates of $\mathrm{Al}(\mathrm{OTF})_{3}$.

Based on these results the following dissociation reactions for Al-triflate in THF can be proposed:

$\mathrm{Al}(\mathrm{OTF})_{3}+4 \mathrm{THF} \rightarrow \mathrm{Al}(\mathrm{THF})_{4}^{3+}+3 \mathrm{OTF}^{-}$

$\mathrm{Al}(\mathrm{OTF})_{3}+4 \mathrm{THF} \rightarrow\left[\mathrm{Al}(\mathrm{THF})_{4}(\mathrm{OTF})\right]^{2+}+2 \mathrm{OTF}^{-}$

$\mathrm{Al}(\mathrm{OTF})_{3}+4 \mathrm{THF} \rightarrow\left[\mathrm{Al}(\mathrm{THF})_{2}(\mathrm{OTF})_{2}\right]^{1+}+\mathrm{OTF}^{-}$

With considerable knowledge of the $\mathrm{Al}(\mathrm{OTF})_{3} / \mathrm{THF}$ spectroscopic features in hand, the reaction between $\mathrm{Al}(\mathrm{OTF})_{3}$ and $\mathrm{LiCl}$ in THF can now be studied. The progress of this reaction is depicted in the inset of Fig. $2 b$ (See also Fig. S1). As $\mathrm{LiCl}$ is introduced to a $0.1 \mathrm{M} \mathrm{Al}(\mathrm{OTF})_{3}$ solution at mole ratios equal to or above 1:2, a transfer of the $\mathrm{OTF}^{-}$from Al- to Li-ions is evident. This is illustrated by the peak shift from 1238 to 1253 $\mathrm{cm}^{-1}$, which, according to our DFT calculations, may be assigned to $\mathrm{Al}-\mathrm{CIP}^{1}$ and $\mathrm{Li}-\mathrm{CIP}$, respectively. At 1:3 mole ratios, this region of the spectrum is identical to that of a solution of $0.4 \mathrm{M} \mathrm{LiOTF}$ in THF. Thus, one may infer that a double displacement reaction between $\mathrm{Al}(\mathrm{OTF})_{3}$ and $\mathrm{LiCl}$ takes place at 1:3 mole ratio according to reaction 4 . While $\mathrm{Li}$ cations have $\mathrm{OTF}^{-}$in their vicinity, the formation of LiOTF ionic aggregates can be excluded from the 1:3 electrolyte due to the absence of the peak at $1047 \mathrm{~cm}^{-1}$, which is typically attributed to LiOTF aggregates, ${ }^{69}$ and the shoulder peak at $1269 \mathrm{~cm}^{-1}$, observed only in the $0.75 \mathrm{M}$ LiOTF / THF solution.

After establishing that the 1:3 electrolytes are primarily comprised of $\mathrm{AlCl}_{3}$ and $\mathrm{LiOTF}$, inspecting ionic species previously reported for $\mathrm{AlCl}_{3}$ /THF solutions is crucial. Alves et al. investigated $\mathrm{AlCl}_{3} / \mathrm{THF}$ solutions by Raman spectroscopy and deduced that these electrolytes were dominated by $\mathrm{AlCl}_{4}^{-}$ in dilute systems whereas $\mathrm{AlCl}_{3}$ (THF) $)_{3}$ are favored at higher concentrations. ${ }^{70}$ On the other hand, Derouault et al. investigated $\mathrm{Al}$-halide $\left(\mathrm{AlCl}_{3}\right.$ or $\left.\mathrm{AlBr}_{3}\right)$ in THF by FTIR and NMR spectroscopy, ${ }^{67}$ and the results were compared to the FTIR and Raman spectra of solid Al-halide complexes. ${ }^{71}$ The latter concluded that dissolving $\mathrm{AlCl}_{3}$ in THF produced mainly $\mathrm{AlCl}_{3}$ (THF) , cis- and trans- isomers of $\mathrm{AlCl}_{3}(\mathrm{THF})_{2}$, and $\mathrm{AlCl}_{4}^{-}$ and $\left[\mathrm{AlCl}_{2}(\mathrm{THF})_{4}\right]^{+}$which resulted from slight dissociation of $\mathrm{AlCl}_{3}$ (THF) $)_{2}$ according to a proposed equilibria which is provided in the ESI.

We note that our FTIR spectra for $\mathrm{AlCl}_{3} / \mathrm{THF}$ appear identical to those of Derouault et al. ${ }^{67}$ The spectra comparison with the $\mathrm{AlCl}_{3}+\mathrm{LiCl} / \mathrm{THF}$ solution is shown in Fig. 2(c and d).
The distinct broad-band centered around $490 \mathrm{~cm}^{-1}$, observed for all measured concentrations of the $\mathrm{AlCl}_{3} / \mathrm{THF}$ solutions, has been assigned to the $v(\mathrm{Al}-\mathrm{Cl})$ of $\mathrm{AlCl}_{3}$ (THF $)_{2}$ and $\mathrm{AlCl}_{4}^{-}$ at $490 \mathrm{~cm}^{-1}$ and $494 \mathrm{~cm}^{-1}$, respectively. ${ }^{67}$ Comparatively, our DFT calculations suggest a peak for the $v_{\text {as }}(\mathrm{Al}-\mathrm{Cl})$ at 476 and $488 \mathrm{~cm}^{-1}$ for the trans- $\mathrm{AlCl}_{3}$ (THF) $)_{2}$ and a peak for the triply degenerate $v_{\text {as }}(\mathrm{Al}-\mathrm{Cl})$ stretch for $\mathrm{AlCl}_{4}^{-}$at $477 \mathrm{~cm}^{-1}$. Surprisingly, these peaks are absent in the $1: 3$ and $1: 4$ electrolytes, yet a weak-intensity peak is observed at $490 \mathrm{~cm}^{-1}$ for the 1:5 electrolyte. These intriguing disparities suggest that the peak at $490 \mathrm{~cm}^{-1}$ is attributed to $\mathrm{AlCl}_{3}$ (THF) $)_{2}$ rather than $\mathrm{AlCl}_{4}^{-}$. The absence of a peak at $477 \mathrm{~cm}^{-1}$ associated with $\mathrm{AlCl}_{4}^{-}$ is probably due to the strong perturbation of the tetrahedral symmetry of $\mathrm{AlCl}_{4}^{-}$caused by the presence of excess amounts of $\mathrm{Li}^{+}$, a phenomenon which has previously been reported for $\mathrm{LiAlCl}_{4}$ melts. ${ }^{72}$

Additionally, DFT calculations suggest that the most thermodynamically favored reaction is that of $\mathrm{AlCl}_{3}$ and $\mathrm{Cl}^{-}$to produce $\mathrm{AlCl}_{4}^{-}$(Table S3). To confirm the presence of $\mathrm{AlCl}_{4}^{-}$in these electrolytes, the $800-1800 \mathrm{~cm}^{-1}$ regions of the spectra shown in Fig. $2 d$ were examined. A broad peak $\sim 1640 \mathrm{~cm}^{-1}$ emerges at 1:3 mole ratios, this peak is also present in dilute $(0.1 \mathrm{M})$ and concentrated $(0.75 \mathrm{M}) \mathrm{AlCl}_{3} / \mathrm{THF}$ solutions. A similar band has been reported for $\mathrm{AlCl}_{4}^{-}$analogs, ${ }^{73}$ which supports assigning this peak to $\mathrm{AlCl}_{4}^{-}$.

In accordance with these findings, we propose the following dissociation mechanisms for the reaction between $\mathrm{Al}(\mathrm{OTF})_{3}$ and $\mathrm{LiCl}$ in $\mathrm{THF}$ at 1:3 mole ratio:

$\mathrm{Al}(\mathrm{OTF})_{3}+3 \mathrm{LiCl}+2 \mathrm{THF} \rightarrow \mathrm{AlCl}_{3}(\mathrm{THF})_{2}+3 \mathrm{LiOTF}$

$\mathrm{AlCl}_{3}(\mathrm{THF})_{2}+\mathrm{Cl}^{-} \rightleftharpoons \mathrm{AlCl}_{4}^{-}+2 \mathrm{THF}$

Only when the amount of $\mathrm{LiCl}$ added to a $0.1 \mathrm{M} \mathrm{Al}(\mathrm{OTF})_{3} / \mathrm{THF}$ solution exceeded a 1:4 molar ratio did a peak appear at 490 $\mathrm{cm}^{-1}$, indicating that an equilibrium exists between $\mathrm{AlCl}_{3}$ (THF) $)_{2}$ and $\mathrm{AlCl}_{4}^{-}$with the former being produced only when substantial amounts of $\mathrm{AlCl}_{4}^{-}$have formed. This observation can be supported by the fact that THF is a much weaker Lewis base than $\mathrm{Cl}^{-}$.

Moreover, the weak-intensity peak observed at $\sim 381 \mathrm{~cm}^{-1}$ in the $1: 2$ solutions, concealed by an overlapping broad-band from LiOTF at higher mole ratios, is probably associated with $\left[\mathrm{AlCl}_{2}(\mathrm{THF})_{4}\right]^{+}$, previously reported $\sim 360 \mathrm{~cm}^{-1} .{ }^{67}$ The broad peak at $407 \mathrm{~cm}^{-1}$ is attributed to $v(\mathrm{Al}-0)^{67}$ as supported by our DFT calculations for $\mathrm{AlCl}_{3}$ (THF) (Table S1). Other bands attributed to this complex according to our DFT calculations are the peak at $\sim 524 \mathrm{~cm}^{-1}$ (Fig. 2c) associated with $v_{\text {as }}(\mathrm{Al}-\mathrm{Cl}$ ), and the peak at $880 \mathrm{~cm}^{-1}$ (Fig. 2d) associated with $v(\mathrm{Al}-\mathrm{O})$ coupled with $\tau\left(\mathrm{CH}_{2}\right)$ (Table S1).

Finally, the vibrational frequencies of polymeric $\mathrm{AlCl}_{4}^{-}$, namely $\mathrm{Al}_{2} \mathrm{Cl}_{7}^{-}$and $\mathrm{Al}_{3} \mathrm{Cl}_{10}^{-}$were calculated using DFT. Our results indicate that both species would have bands in the 200-600 
(a)

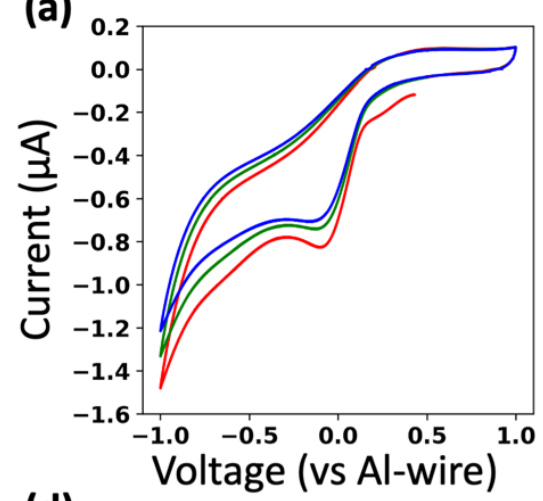

(d)

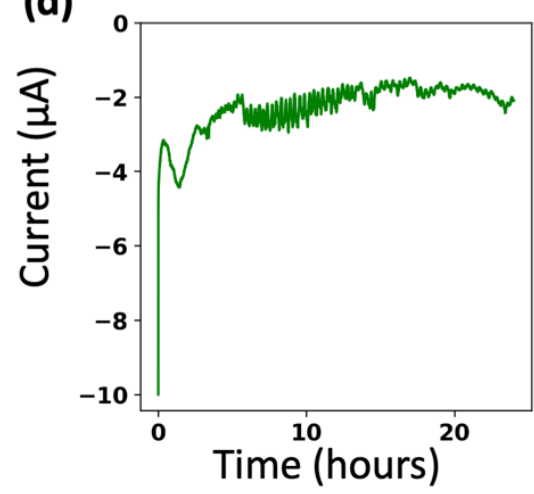

(b)

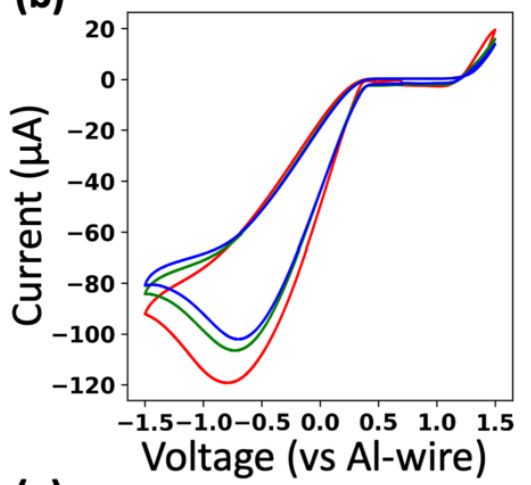

(e)

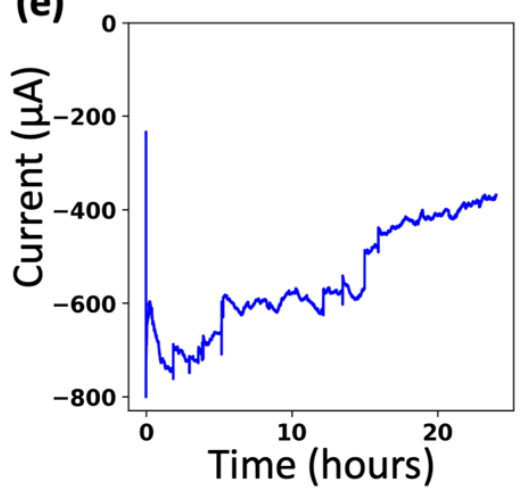

(c)

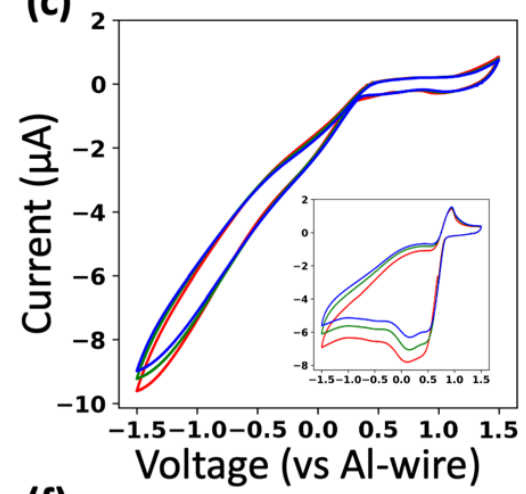

(f)

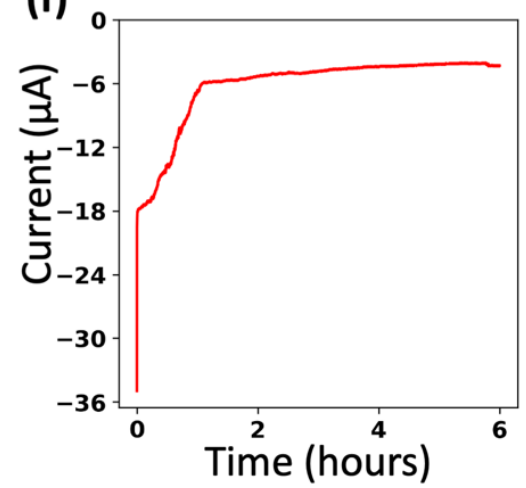

Fig. 3 Cyclic voltammograms on gold working electrode at $50 \mathrm{mV} / \mathrm{s}$ scan rate for (a) $0.1 \mathrm{M} \mathrm{Al}(\mathrm{OTF})_{3} / \mathrm{THF}$, (b) $1: 3 \mathrm{Al}(\mathrm{OTF})_{3}: \mathrm{LiCl} / \mathrm{THF}$ and (c) $0.1 \mathrm{M} \mathrm{AlCl}{ }_{3} / \mathrm{THF}$ with inset showing $0.75 \mathrm{M} \mathrm{AlCl}_{3} / \mathrm{THF}$, and corresponding chronoamperograms on $\mathrm{Cu}$-substrate of (d) $0.1 \mathrm{M} \mathrm{Al}(\mathrm{OTF})_{3} / \mathrm{THF}$ at $\mathrm{OV},(\mathrm{e}) 1: 3 \mathrm{Al}(\mathrm{OTF})_{3}: \mathrm{LiCl} / \mathrm{THF}$ at $+0.25 \mathrm{~V}$ and $(\mathrm{f}) 0.1 \mathrm{M}$ $\mathrm{AlCl}_{3} / \mathrm{THF}$ at $+0.25 \mathrm{~V}$ (vs. Al/ $/ \mathrm{Al}^{3+}$ ).

$\mathrm{cm}^{-1}$ region. Although several peaks are observed at various concentrations in said region, it's highly unlikely that these peaks are attributable to polymeric $\mathrm{AlCl}_{4}^{-}$. The only report of such species in similar systems, to our knowledge, is that of $\mathrm{AlCl}_{3} / \mathrm{GBL}$ solutions where the presence of $\mathrm{Al}_{3} \mathrm{Cl}_{10}^{-}$was proposed at considerably high concentrations. ${ }^{55}$ Thus, polymerization of $\mathrm{AlCl}_{4}^{-}$in THF, although possible, is unlikely to occur in dilute solutions $(<1 \mathrm{M})$, such as those studied here.

To evaluate the electrochemical behaviour of these electrolytes, cyclic voltammetry (CV) experiments were performed for 0.1M Al(OTF) $)_{3} / \mathrm{THF}, 1: 3 \mathrm{Al}(\mathrm{OTF})_{3}+\mathrm{LiCl} / \mathrm{THF}$ and $0.1 \mathrm{M} \mathrm{AlCl}_{3} / \mathrm{THF}$ using a gold working electrode in a standard three electrode setup, the results of which are shown in Fig. 3. The CV for 0.1M Al(OTF) $)_{3} / \mathrm{THF}$ electrolyte (Fig. 3a) reveals the electrochemical reduction of $\mathrm{Al}$-ions with an onset reduction potential ca. $+0.15 \mathrm{~V}$ (vs. $\mathrm{Al} / \mathrm{Al}^{3+}$ ). The addition of $\mathrm{LiCl}$ at a 1:3 mole ratio (Fig. $3 \mathrm{~b}$ ) results in a shift in reduction potential to ca. $+0.4 \mathrm{~V}$ along with a dramatic increase in current, suggesting more facile $\mathrm{Al}$ electrodeposition in $\mathrm{Cl}^{-}$rich environment, similar to shifts observed in the magnesium aluminum chloride complex electrolyte. ${ }^{74}$ This electrolyte also exhibits a broad cathodic wave that extends beyond $-1 \mathrm{~V}$, possibly due to co-deposition of Li which is expected around this potential versus the $\mathrm{Al}$ wire. $\mathrm{CV}$ measurements for the 1:2 mole solution were hindered by the formation of a gas bubble on the surface of the gold electrode, whereas the 1:4 and 1:5 solutions exhibited a similar CV profile to that of the 1:3 electrolyte (Fig. S3).
In contrast, the $\mathrm{AlCl}_{3} / \mathrm{THF}$ electrolyte exhibits a non-diffusion controlled electrochemical reduction ca. OV for the $0.1 \mathrm{M}$ solution (Fig. 3c) while a drastic shift in reduction potential is evident at higher concentrations (0.75M) (inset of Fig. 3c). Two adjoint cathodic waves are observed ca. $+0.25 \mathrm{~V}$, which we attribute to the electrochemical reduction of $\mathrm{Al}$-ions. The shift in electrochemical activity as a function of increasing $\mathrm{AlCl}_{3} / \mathrm{THF}$ concentration is shown in Fig. S2. Additionally, an anodic peak is evident ca. $+0.8 \mathrm{~V}$ in the most concentrated $\mathrm{AlCl}_{3} / \mathrm{THF}$ solutions, this oxidative feature may have arisen as a result of partial Al-stripping caused by the increased acidity of the solution, likely due to the formation of $\mathrm{AlCl}_{3}$ (THF) as we have previously revealed by DFT/FTIR analyses.

To further understand the nature of the acidic environment causing these immense differences in electrochemical behavior of $\mathrm{Al}$-ions in the $\mathrm{Cl}^{-}$rich environments $(1: 3$ and $0.75 \mathrm{M}$ $\mathrm{AlCl}_{3} / \mathrm{THF}$ ), a clear description of the ionic profile of both electrolytes is necessary. According to previously discussed spectroscopy analyses, the electrochemically active $\mathrm{Al}$ species in the 1:3 electrolyte is likely the anionic species $\mathrm{AlCl}_{4}^{-}$arising from ligand transfer which is promoted by excess amounts of $\mathrm{LiCl}$. In this system, $\mathrm{AlCl}_{4}^{-}$is associated with $\mathrm{Li}-\mathrm{OTF} \mathrm{CIP}$.

Comparatively, $\mathrm{Al}$ speciation in $\mathrm{AlCl}_{3} / \mathrm{THF}$ is much more diverse, and the origin of $\mathrm{AlCl}_{4}^{-}$is intricate. It is well known that $\mathrm{AlCl}_{3}$ dimers may undergo symmetric and/or asymmetric cleavage when dissolved in ethereal organic solvents. ${ }^{57,75}$ While DFT calculations revealed that both processes are equally plausibale in $\mathrm{THF},{ }^{76}$ experimental evidence repeatedly 
corroborates that these solutions are dominated by $\mathrm{AlCl}_{3}(\mathrm{THF})_{2} . .^{74,77}$ Interestingly, temperature dependant NMR spectroscopy for this system suggested that $\mathrm{AlCl}_{3}$ (THF) $)_{2}$ undergoes self ionization to produce $\left[\mathrm{AlCl}_{4}^{-}\right]\left[\mathrm{AlCl}_{2}^{+}(\mathrm{THF})_{4}\right]{ }^{67,78}$ Hence, the acidic character of the $\mathrm{AlCl}_{3} / \mathrm{THF}$ solution is perhaps also due to ionic association of the $\mathrm{AlCl}_{4}^{-}$to the highly acidic $\left[\mathrm{AlCl}_{2}^{+}(\mathrm{THF})_{4}\right]$ rather than the charge neutral Li - OTF CIP.

To gauge the likelihood of aluminum deposition, chronoamperometry was carried out on these three systems, in dilute solutions $([\mathrm{Al}]=0.1 \mathrm{M})$ using a $\mathrm{Cu}$ foil substrate in a standard three electrode setup. Chronoamperograms corresponding to Al-plating from $0.1 \mathrm{M} \mathrm{Al}(\mathrm{OTF})_{3} / \mathrm{THF}, 1: 3$ $\mathrm{Al}(\mathrm{OTF})_{3}: \mathrm{LiCl} / \mathrm{THF}$ and $0.1 \mathrm{M} \mathrm{AlCl}_{3} / \mathrm{THF}$ are shown in Fig. $3 \mathrm{~d}$, $\mathrm{e}$ and $\mathrm{f}$, respectively. The potential for the $\mathrm{Al}(\mathrm{OTF})_{3} / \mathrm{THF}$ electrolyte was set to $\mathrm{OV}$ vs. $\left(\mathrm{Al} / \mathrm{Al}^{3+}\right)$, whereas the potential for the $\mathrm{AlCl}_{3} / \mathrm{THF}$ and 1:3 electrolyte was set to +0.25V (vs. $\mathrm{Al} / \mathrm{Al}^{3+}$ ). Over the course of these chronoamperometry experiment, a cathodic current was obtained for all three electrolytes. Despite the significantly lower electrodeposition potential of the 1:3 electrolyte, the measured current in this electrolyte is at least 2 orders of magnitudes higher than that of the $\mathrm{Al}(\mathrm{OTF})_{3} / \mathrm{THF}$ electrolyte. The total charge passed was calculated by integrating the chronoamperometry curves, and was found to be $-196.3 \mathrm{mC},-47.47 \mathrm{C}$, and $-131.8 \mathrm{mC}$ for the Altriflate/THF, 1:3 Al-triflate:LiCl/THF and $\mathrm{AlCl} 3 / \mathrm{THF}$, respectively. To confirm that the reductive processes observed in cyclic voltammetry and chronoamperometry plots correspond to electrochemical reduction of $\mathrm{Al}$-ions to Al-metal, a scanning electron microscope (SEM) was used to evaluate the surface morphology of the $\mathrm{Cu}$ substrates. Fig. 4 shows a series of SEM images of an untreated $\mathrm{Cu}$ substrate $(\mathrm{a}, \mathrm{b}), \mathrm{Al}$ deposits obtained from $\mathrm{Al}(\mathrm{OTF})_{3} / \mathrm{THF}(\mathrm{c}, \mathrm{d}), 1: 3$ electrolyte $(\mathrm{e}, \mathrm{f})$, and $\mathrm{AlCl}_{3} / \mathrm{THF}$ (g-h).

Low magnification SEM images (Fig. S4) show that the 1:3 electrolyte exhibits high corrosivity as evident by the dark pits on the surface of the $\mathrm{Al} / \mathrm{Cu}$. High magnification SEM imaging for the $\mathrm{Al}$ deposits obtained from $\mathrm{Al}(\mathrm{OTF})_{3} / \mathrm{THF}$ reveal that these deposits undergo structural rearrangement during deposition to form streaks of nanoparticle agglomerates as shown in (Fig. S6) probably due to the non-homogenous surface of the Cu substrates.

To summarize, FTIR measurements complemented by DFT calculations provided unique insight into $\mathrm{Al}$ complex ion formation in $\mathrm{Cl}^{-}$free $\left(\mathrm{Al}(\mathrm{OTF})_{3} / \mathrm{THF}\right)$ and $\mathrm{Cl}^{-}$rich $\left(\mathrm{AlCl}_{3} / \mathrm{THF}\right.$ and $\left.\mathrm{Al}(\mathrm{OTF})_{3}+\mathrm{LiCl} / \mathrm{THF}\right)$ environments. The spectral features associated with the $\mathrm{OTF}^{-}$anion were highlighted for the purpose of measuring the effect of $\mathrm{Cl}^{-}$on Al-ion speciation and subsequently, the electrochemical behaviour of $\mathrm{Al}$-ions. At the cost of high corrosivity, $\mathrm{Cl}^{-}$ significantly enhances the electrochemical activity of Al-ions. Spectral analyses coupled with CV measurements for the $\mathrm{Cl}^{-}$ rich systems suggest that a sufficiently acidic ionic environment may enable stripping of $\mathrm{Al}$ in THF. Finally, Al nanoparticles were deposited potentiostatically from dilute solutions ([Al] $=0.1 \mathrm{M}$ ) of all three systems.

\section{Outlook}

Organic electrolytes for Al-ion battery application are generally overlooked due to their volatility and high flammability. However, operational organic electrolytes typically comprise of concentrated electrolytes where the effect of free solvent is diminished leading to low volatility. ${ }^{53}$ With regards to the flammability of these systems, this hurdle may be overcome by exploring additives that inhibit flammability via routes similar to those investigated for $\mathrm{Li}$-ion ${ }^{79}$ and $\mathrm{Na}$-ion ${ }^{80}$ electrolytes.

We speculate that $\mathrm{Al}$ can be electrochemically deposited from organic solvents of similar properties using $\mathrm{Al}(\mathrm{OTF})_{3}$. Extending this work to other systems while exploring numerous additives may provide profound understanding of $\mathrm{Al}$-anion and Al-solvent interactions which could potentially lead to an optimized, non-corrosive and safe organic electrolyte for practical $\mathrm{Al}$-ion battery application.

\section{Author Contributions}

E.J.M: Conceptualization, Funding acquisition, Methodology, Project administration, Resources, Supervision, Validation, Writing - review \& editing. Z.S: Data Curation, Formal analysis, Investigation, Software, Visualization, Writing - original draft.

\section{Corresponding Author: Erik J. Menke Email: emenke@ucmerced.edu}

\section{Acknowledgements}

The authors acknowledge computing time on MultiEnvironment Computer for Exploration and Discovery (MERCED) Cluster which is supported by National Science Foundation Grant no. ACl-1429783. Electron microscopy resources were provided by Imaging and Microscopy Facility (IMF) at UC Merced. Z.S thanks Kennedy Nguyen for helpful discussions on electron microscopy. Z.S is thankful to Hassan Harb for invaluable discussions on computational methodology.

\section{Conflicts of interest}

The authors declare no competing interests. 


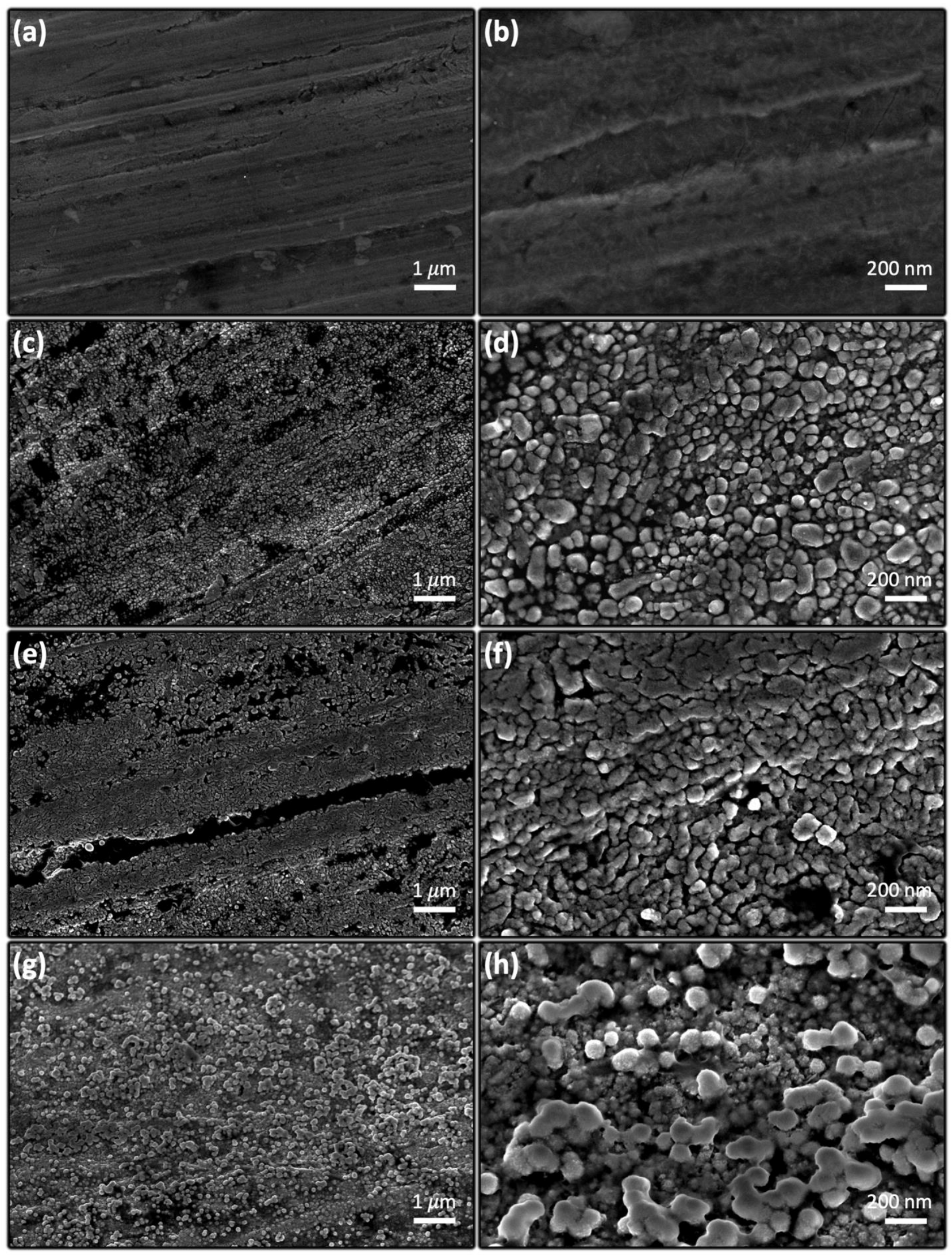

Fig. 4 SEM images of (a-b) untreated Cu substrate, Al electrodeposits on Cu-substrate (vs. Al/ $\mathrm{Al}^{3+}$ ) obtained from (c-d) $0.1 \mathrm{M} \mathrm{Al}(\mathrm{OTF})_{3} / \mathrm{THF}$ at $0 \mathrm{~V}$ for 24 hours, (e-f) 1:3 $\mathrm{Al}(\mathrm{OTF})_{3}$ : $\mathrm{LiCl} / \mathrm{THF}$ at $+0.25 \mathrm{~V}$ for 24 hours and (g-h) $0.1 \mathrm{M} \mathrm{AlCl} 3 / \mathrm{THF}$ at $+0.25 \mathrm{~V}$ for 6 hours. 


\section{References}

1 S. Jaffe, Joule, 2017, 1, 225-228.

2E. A. Olivetti, G. Ceder, G. G. Gaustad and X. Fu, Joule, 2017, 1, 229-243.

3 Y. Liang, H. Dong, D. Aurbach and Y. Yao, Nat. Energy, 2020, 5, 646-656.

4 M. Li, J. Lu, X. Ji, Y. Li, Y. Shao, Z. Chen, C. Zhong and K. Amine, Nat. Rev. Mater., 2020, 5, 276-294.

5 J. Muldoon, C. B. Bucur and T. Gregory, Chem. Rev., 2014, 114, 11683-11720.

6 J. Tu, W.-L. Song, H. Lei, Z. Yu, L.-L. Chen, M.

Wang and S. Jiao, Chem. Rev., 2021, 121, 4903-4961.

7 E. Faegh, B. Ng, D. Hayman and W. E. Mustain, Nat. Energy, 2021, 6, 21-29.

8Z. A. Zafar, S. Imtiaz, R. Razaq, S. Ji, T. Huang, Z. Zhang, Y. Huang and J. A. Anderson, J. Mater. Chem. A, 2017, 5, 5646-5660.

9F. Wu, H. Yang, Y. Bai and C. Wu, Adv. Mater., 2019, 31, 1806510.

10 O. M. Leung, T. Schoetz, T. Prodromakis and C. P. de León, J. Electrochem. Soc., 2021, 168, 056509.

11 Y. Zhang, S. Liu, Y. Ji, J. Ma and H. Yu, $A d v$. Mater., 2018, 30, 1706310.

12 N. Jayaprakash, S. K. Das and L. A. Archer, Chem. Commun., 2011, 47, 12610-12612.

13 L. D. Reed and E. Menke, J. Electrochem. Soc., 2013, 160, A915.

14 L. Geng, G. Lv, X. Xing and J. Guo, Chem. Mater., 2015, 27, 4926-4929.

15 M.-C. Lin, M. Gong, B. Lu, Y. Wu, D.-Y. Wang, M. Guan, M. Angell, C. Chen, J. Yang and B.J. Hwang, Nature, 2015, 520, 324-328.

16 T. Gao, X. Li, X. Wang, J. Hu, F. Han, X. Fan, L. Suo, A. J. Pearse, S. B. Lee and G. W. Rubloff, Angew. Chem., Int. Ed., 2016, 128, 10052-10055.

17 N. P. Stadie, S. Wang, K. V. Kravchyk and M. V. Kovalenko, ACS nano, 2017, 11, 1911-1919.

18 G. A. Elia, I. Hasa, G. Greco, T. Diemant, K. Marquardt, K. Hoeppner, R. J. Behm, A. Hoell, S. Passerini and R. Hahn, J. Mater. Chem. A, 2017, 5, 9682-9690.

19 K. V. Kravchyk, S. Wang, L. Piveteau and M. V. Kovalenko, Chem. Mater., 2017, 29, 4484-4492.

20 H. Tian, S. Zhang, Z. Meng, W. He and W.-Q. Han, ACS Energy Lett., 2017, 2, 1170-1176.

21 M. Walter, K. V. Kravchyk, C. Böfer, R.

Widmer and M. V. Kovalenko, Adv. Mater., 2018, 30, 1705644.

22 S. Wang, K. V. Kravchyk, A. N. Filippin, U. Müller, A. N. Tiwari, S. Buecheler, M. I. Bodnarchuk and M. V. Kovalenko, Adv. Sci., 2018, 5, 1700712.
23 D. Muñoz-Torrero, P. Leung, E. GarcíaQuismondo, E. Ventosa, M. Anderson, J. Palma and R. Marcilla, J. Power Sources, 2018, 374, 77-83.

24 H. Chen, H. Xu, S. Wang, T. Huang, J. Xi, S. Cai, F. Guo, Z. Xu, W. Gao and C. Gao, Sci. Adv., 2017, 3, eaao7233.

25 C. Yang, S. Wang, X. Zhang, Q. Zhang, W. Ma, S. Yu and G. Sun, J. Phys. Chem. C, 2019, 123, 11522-11528.

26 D. J. Kim, D.-J. Yoo, M. T. Otley, A.

Prokofjevs, C. Pezzato, M. Owczarek, S. J. Lee, J. W.

Choi and J. F. Stoddart, Nat. Energy, 2019, 4, 51-59.

27 Q. Zhou, D. Wang, Y. Lian, S. Hou, C. Ban, Z.

Wang, J. Zhao and H. Zhang, Electrochim. Acta, 2020, 354, 136677.

28 Q. Zhao, J. Zheng, Y. Deng and L. Archer, J. Mater. Chem. A, 2020, 8, 23231-23238.

29 H. Wang, S. Gu, Y. Bai, S. Chen, N. Zhu, C. Wu and F. Wu, J. Mater. Chem. A, 2015, 3, 2267722686.

30 P. K. Lai and M. Skyllas-Kazacos, $J$.

Electroanal. Chem, 1988, 248, 431-440.

31 R. T. Carlin, W. Crawford and M. Bersch, $J$.

Electrochem. Soc., 1992, 139, 2720.

32 H. Yang, H. Li, J. Li, Z. Sun, K. He, H.-M.

Cheng and F. Li, Angew. Chem., Int. Ed., 2019, 58, 11978-11996.

33 D. E. Couch and A. Brenner, J. Electrochem. Soc., 1952, 99, 234.

34 N. Ishibashi and M. Yoshio, Electrochim. Acta, 1972, 17, 1343-1352.

35 W. A. Badawy, B. A. Sabrah and N. H. Y.

Hilal, J. Appl. Electrochem., 1987, 17, 357-369.

36 M. Yoshio and N. Ishibashi, J. Appl.

Electrochem., 1973, 3, 321-325.

37 M. W. M. Graef, J. Electrochem. Soc., 1985, 132, 1038.

38 M. C. Lefebvre and B. E. Conway, J.

Electroanal. Chem., 2000, 480, 34-45.

39 M. C. Lefebvre and B. E. Conway, J.

Electroanal. Chem., 2000, 480, 46-58.

40 G. A. Capuano and W. G. Davenport, $J$.

Electrochem. Soc., 1971, 118, 1688.

41 E. Peled and E. Gileadi, J. Electrochem. Soc., 1976, 123, 15.

42 T. Hisano, T. Terazawa, I. Takeuchi, S. Inohara and H. Ikeda, Bull. Chem. Soc. Jpn., 1971, 44, 599603.

43 N. Yitzhack, P. Tereschuk, N. Sezin, D.

Starosvetsky, A. Natan and Y. Ein-Eli, J. Solid State Electrochem, 2020, 24, 2833-2846.

44 L. Legrand, A. Tranchant and R. Messina, Electrochim. Acta, 1994, 39, 1427-1431. 
45 L. Legrand, A. Tranchant and R. Messina, J. Electrochem. Soc., 1994, 141, 378.

46 L. Legrand, M. Heintz, A. Tranchant and R. Messina, Electrochim. Acta, 1995, 40, 1711-1716.

47 L. Legrand, A. Tranchant and R. Messina, Electrochim. Acta, 1996, 41, 2715-2720.

48 Y. Nakayama, Y. Senda, H. Kawasaki, N. Koshitani, S. Hosoi, Y. Kudo, H. Morioka and M. Nagamine, Phys. Chem. Chem. Phys., 2015, 17, 57585766

49 M. Miyake, H. Fujii and T. Hirato, Surf. Coat. Technol., 2015, 277, 160-164.

50 A. Kitada, K. Nakamura, K. Fukami and K. Murase, Electrochemistry, 2014, 82, 946-948.

51 A. Kitada, K. Nakamura, K. Fukami and K. Murase, Electrochim. Acta, 2016, 211, 561-567.

52 A. KITADA, Y. KATO, K. FUKAMI and K. MURASE, Journal of The Surface Finishing Society of Japan, 2018, 69, 310-311.

53 Z. Zhang, A. Kitada, S. Gao, K. Fukami, N. Tsuji, Z. Yao and K. Murase, ACS Appl. Mater. Interfaces, 2020, 12, 43289-43298.

54 B. Zhang, Z. Shi, L. Shen, A. Liu, J. Xu and X. Hu, J. Electrochem. Soc., 2018, 165, D321.

55 X. Wen, Y. Liu, D. Xu, Y. Zhao, R. K. Lake and J. Guo, J. Phys. Chem. Lett., 2020, 11, 15891593.

56 J. Shi, J. Zhang and J. Guo, ACS Energy Lett., 2019, 4, 2124-2129.

57 T. Mandai and P. Johansson, J. Phys. Chem. C, 2016, 120, 21285-21292.

58 M. Chiku, S. Matsumura, H. Takeda, E. Higuchi and H. Inoue, J. Electrochem. Soc., 2017, 164, A1841.

59 X. Wen, J. Zhang, H. Luo, J. Shi, C. Tsay, H. Jiang, Y.-H. Lin, M. A. Schroeder, K. Xu and J. Guo, J. Phys. Chem. Lett., 2021, 12, 5903-5908.

60 L. D. Reed, S. N. Ortiz, M. Xiong and E. J. Menke, Chem. Commun., 2015, 51, 14397-14400.

61 L. D. Reed, A. Arteaga and E. J. Menke, J. Phys. Chem. B, 2015, 119, 12677-12681.

62 T. Mandai and P. Johansson, J. Mater. Chem. A, 2015, 3, 12230-12239.

63 Z. Slim and E. J. Menke, J. Phys. Chem. B, 2020, 124, 5002-5008.

64 C. Wu, S. Gu, Q. Zhang, Y. Bai, M. Li, Y. Yuan, H. Wang, X. Liu, Y. Yuan and N. Zhu, Nat. Commun, 2019, 10, 1-10.

65 C. Yan, C. Lv, L. Wang, W. Cui, L. Zhang, K. N. Dinh, H. Tan, C. Wu, T. Wu and Y. Ren, J. Am. Chem. Soc., 2020, 142, 15295-15304.

66 H. Wang, S. Gu, Y. Bai, S. Chen, F. Wu and C. Wu, ACS Appl. Mater. Interfaces, 2016, 8, 2744427448 .
67 J. Derouault, P. Granger and M. T. Forel, Inorg. Chem., 1977, 16, 3214-3218.

68 A. Bernson and J. Lindgren, Solid State Ion., 1993, 60, 31-36.

69 W. Huang, R. Frech and R. A. Wheeler, J. Phys. Chem., 1994, 98, 100-110.

70 C. C. Alves, T. B. Campos and W. A. Alves, Spectrochim. Acta A, 2012, 97, 1085-1088.

71 J. Derouault and M. T. Forel, Inorg. Chem., 1977, 16, 3207-3213.

72 R. J. Gale and R. A. Osteryoung, Inorg. Chem., 1980, 19, 2240-2242.

73 R. Kore, S. P. Kelley, P. Aduri and R. D.

Rogers, Dalton Trans., 2018, 47, 7795-7803.

74 K. A. See, Y.-M. Liu, Y. Ha, C. J. Barile and A. A. Gewirth, ACS Appl. Mater. Interfaces, 2017, 9, 35729-35739.

75 A. H. Cowley, M. C. Cushner, R. E. Davis and P. E. Riley, Inorg. Chem., 1981, 20, 1179-1181.

76 J. B. Moss, MS Thesis, Utah State University, 2019.

77 M. C. Lefebvre and B. E. Conway, J.

Electroanal. Chem., 1998, 448, 217-227.

78 H. Nöth, R. Rurländer and P. Wolfgardt, Zeitschrift für Naturforschung B, 1982, 37, 29-37.

79 K. Deng, Q. Zeng, D. Wang, Z. Liu, G. Wang, Z. Qiu, Y. Zhang, M. Xiao and Y. Meng, Energy Storage Mater., 2020, 32, 425-447.

80 Y. Yu, H. Che, X. Yang, Y. Deng, L. Li and Z.F. Ma, Electrochem. Commun., 2020, 110, 106635. 